\title{
Research on the slagging characteristics of blended coals in a pilot-scale furnace*
}

\author{
Hao ZHOU ${ }^{\dagger}$, Le-tian LI, Hai-long ZHANG, Bin ZHOU \\ (Institute for Thermal Power Engineering, Zhejiang University, Hangzhou 310027, China) \\ †E-mail: zhouhao@zju.edu.cn \\ Received June 15, 2014; Revision accepted Nov. 20, 2014; Crosschecked Feb. 10, 2015
}

\begin{abstract}
This paper applies digital image techniques to observe the slagging characteristics of blended coals in a pilot-scale furnace. Collected deposit samples were analyzed by scanning electron microscopy linked with energy-dispersive X-ray analysis (SEM-EDX), X-ray diffraction (XRD), and X-ray Fluorescence (XRF) to acquire the microstructure, chemical composition, and mineralogy. The deposit thickness of three blends was analyzed between their parent coal A (Datong) and coal B (Shan), and we noted that the time to reach a stable stage decreased with the ratio of coal B. The addition of coal A into coal B could remarkably restrained the growth and thickness of ash deposits. The results of XRD analysis indicated the initial layer was predominantly comprised of the crystalline minerals quartz, anorthite, or albite except for coal B. All of the blends and coals contained quartz and Ca- to Al-silicates $\left(\mathrm{Ca}_{0.68} \mathrm{Na}_{0.32}\right)\left(\mathrm{Al}_{1.68} \mathrm{Si}_{0.32}\right) \mathrm{Si}_{2} \mathrm{O}_{8}$ in the slag layer where iron-bearing minerals (e.g., ilvaite) were altered into an amorphous phase. The result of SEM-EDX suggested that there was an elemental disparity between the coal ash and deposit.
\end{abstract}

Key words: Blended coal, Ash deposit, Slagging, Charge-coupled device (CCD) camera, Mineralogy doi: 10.1631 jzus.A1400172

Document code: A

CLC number: TQ534

\section{Introduction}

A number of thermal power plants were designed to combust specific fuels. Because supply may be limited or fuels for which the plants were originally designed are now uneconomical, different fuels are now used. Hence, measures should be taken to guarantee the quality of the fuel fired in the furnace (Su, 1999). Blending of coals can be used to satisfy the requirements of given utilities. Possible advantages for power plants include reducing fuel costs, using more acceptable coals, and improving operational performance (Richards et al., 1993; Wang and Harb, 1997; Arvelakis et al., 2006; Ma et al., 2007; Kostakis, 2011).

\footnotetext{
* Project supported by the National Natural Science Foundation of China (No. 51476137)

(b) ORCID: Hao ZHOU, http://orcid.org/0000-0001-9779-7703

(c) Zhejiang University and Springer-Verlag Berlin Heidelberg 2015
}

Although blended coals may have such advantages, the performance of blended coals may not be predicted by interpolating linearly from the performance of the parent coals ( $\mathrm{Su}, 1999)$. Nowadays, the use of several different coals being blended to satisfy power plant requirements has succeeded at some plants, whereas this has caused some unexpected problems at other sites. It is uncertain how a combination of parameters from individual coals will affect power station performance. In the furnace, the interaction between the individual ash particles only happens on the depositional surface and it could be greatly nonlinear (Gupta et al., 2001).

To date, a number of researchers have focused on the characteristics of ash deposition for coal blends, but the effects of coal blending on the operational performance are not completely known.

$\mathrm{Su}$ et al. $(2001 ; 2003)$ presented the experimental results of five pairs of blended coals tested in an Australian Coal Industry Research Laboratory 
(ACIRL) furnace and found that the growth rate, on account of images of fouling deposits, correlated better than other indices, such as the build-up rate. They proposed a minimum heat flux ratio and total heat flux, which were better than visual physical characteristics and the build-up rate, to estimate the slagging propensity of tested blends.

Degereji et al. (2012) developed a computational fluid dynamics code to calculate ash deposition rate and proposed a numerical slagging index based on the properties of coals. The prediction results correlated well with the experimental data of most of blends, while some existing slagging indices showed remarkable inconformity compared to the experimental results.

Rushdi et al. (2004) and Rushdi and Gupta (2005) conducted experiments with Australian black coals and blends. The results showed that deposits developed from different blends could be substantially different from those developed from single coals. This study concluded that the slagging behavior of blends were not additive in nature but instead resulted from the interaction between ash particles within the deposit layers.

The aim of this study is to research the slagging characteristics of blended coals by image processing techniques. In addition, other analytical methods, such as X-ray diffraction (XRD), X-ray fluorescence (XRF), and scanning electron microscopy linked with energydispersive X-ray analysis (SEM-EDX), were used to measure coal blend and ash deposit parameters.

\section{Experimental}

\subsection{Combustion facilities}

Fig. 1 is the schematic diagram of the pilot-scale experiment bench for the blended coal tests in this study. It principally consisted of the vertical furnace, fuel feeder, swirl burner, temperature measurement system, ash deposition sampling system, and image sampling system (Zhou et al., 2012). The height and inner diameter of the furnace were 3950 and $350 \mathrm{~mm}$, respectively. The vertical furnace was covered with refractory material to cut heat dissipation. The fuel feeding rate was controlled at $35 \mathrm{~kg} / \mathrm{h}$ while the experimental condition reached steady state.

A stainless steel probe for deposition was plugged into the center of the furnace at a distance of $1910 \mathrm{~mm}$ from the burner nozzle as shown in Fig. 1. The image sampling system was placed on the opposite end of the deposition probe and applied to observe the deposits growth online. A flue gas pre-processor and analyzer were placed at the bottom of the vertical furnace to measure the concentration of

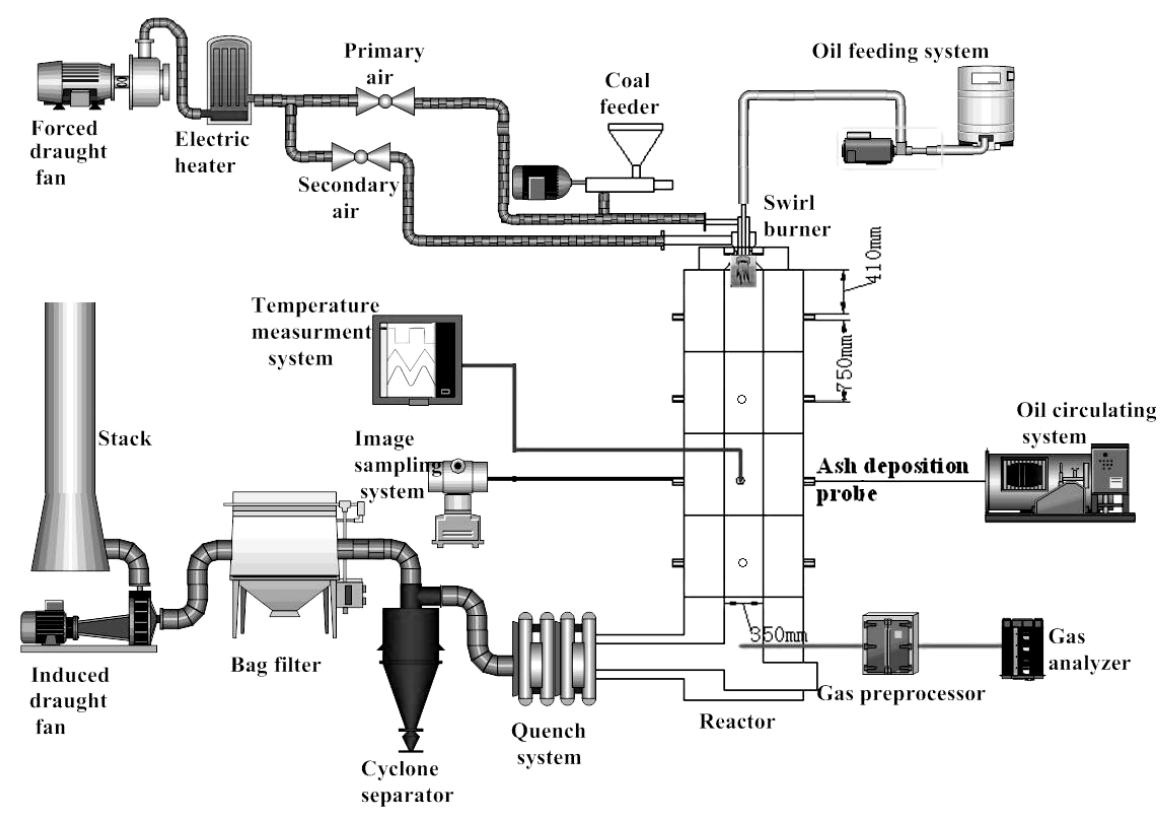

Fig. 1 Schematic diagram of the pulverized coal combustion furnace 
main gas in flue gas, such as $\mathrm{O}_{2}, \mathrm{CO}_{2}, \mathrm{SO}_{2}$, and $\mathrm{NO}_{x}$. Fine fly-ash was removed by the bag filter. At the exit of the vertical furnace, the flue gas was cooled down to about $400{ }^{\circ} \mathrm{C}$ by a direct quench system to keep the flue gas pipeline from overheating. The experimental temperature of the third stage furnace is presented in Fig. 2, which shows significant non-uniformity and fluctuations in temperatures during the pilot-scale experiments.

\subsection{Deposit sampling technology}

The ash-deposition probe was inserted into the furnace when combustion reached required conditions including a furnace temperature of about $1200{ }^{\circ} \mathrm{C}$ and flue-gas oxygen concentration fluctuating between $3.5 \%$ and $4.5 \%$. The process by which ash deposition occurs is illustrated in Fig. 3 and a more detailed description can be found in (Zhou et al., 2012). The deposition probe was in the furnace for $4 \mathrm{~h}$ to collect deposits.

\subsection{Slagging image system and image processing technique}

The ash-deposition growth was observed and recorded by a charge-coupled device (CCD) monitoring system. The schematic diagram and photos of the slagging image system are shown in Fig. 4. The system was cooled by water in the outer channel, while compressed air was introduced to clean and protect the front of the lens. Specific parameters used for the CCD camera were based on Zhou et al. (2012). When one frame of the slagging process was acquired by the CCD camera, it was processed into a binary image using Matlab. After that, the edge of the deposit and probe were detected and then the parameters of the circle were calculated using the Hough transform algorithm. The diameter of the deposition probe $\left(D_{1}\right)$ was set as $40 \mathrm{~mm}$ and was held constant in the experiments. The pixels at the maximum heights of the deposit $h$ and $D_{1}$ were obtained from the images and denoted as $P_{h}$ and $P_{D}$, respectively. Then, the following equation was applied to calculate the thickness of the deposits $(h)$ :

$$
h=D_{1} P_{h} / P_{D} .
$$

The image processing graphical user interface (GUI) is shown in Fig. 5.

\subsection{Fuels analysis}

Two component coals, coal A (Datong) and Coal B (Shan), were chosen for the pilot-scale tests. Three types of blends were formulated from the component coals in different ratios. The blended coals were expressed in weight percentages as $\mathrm{Ab}(75 \%$ coal $\mathrm{A}$, $25 \%$ coal B), AB (50\% coal A, $50 \%$ coal B), and aB ( $25 \%$ coal A, $75 \%$ coal B). The properties of the coals are shown in Table 1 (p.208) and the particle-size distribution is shown in Fig. 6 (p.208).

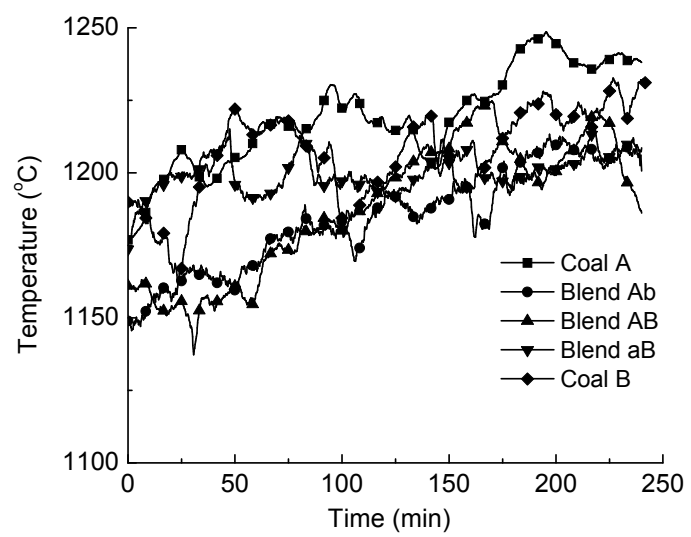

Fig. 2 Temperature of the third stage during the experiments

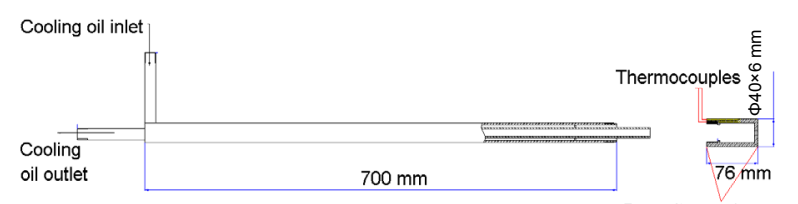

(a)

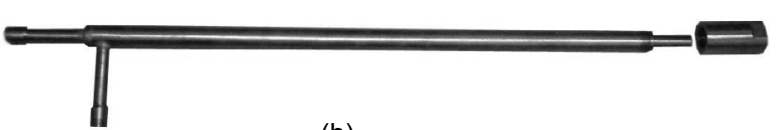

(b)

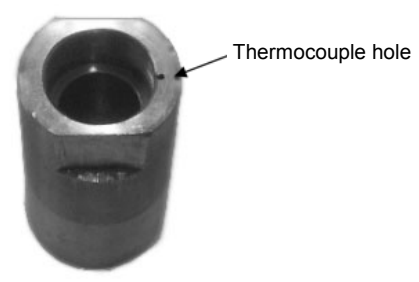

(c)

Fig. 3 Schematic diagram of the deposition probe (a), deposition probe detail (b), and deposition sampling part detail (c) (Zhou et al., 2012) 


\section{Results and discussion}

\subsection{Visual estimate of the ash deposits}

The top view and cross-section of the deposits generated from two coals and three blends are shown in Figs. 7 and 8 (p.209). The lengths of deposits A and $\mathrm{AB}$ were about $147 \mathrm{~mm}$ and $140 \mathrm{~mm}$, remarkably longer than the others (about $75 \mathrm{~mm}$ ) for the bond with the slag out of the sampling port. As shown in Fig. 8, the cross-section of the five slags appears as an irregular-layered structure with gradual changes in the colors and pores. Along the growth direction of the slag, the slag can be approximately divided into three layers: (1) the initial layer; (2) the sintered layer;

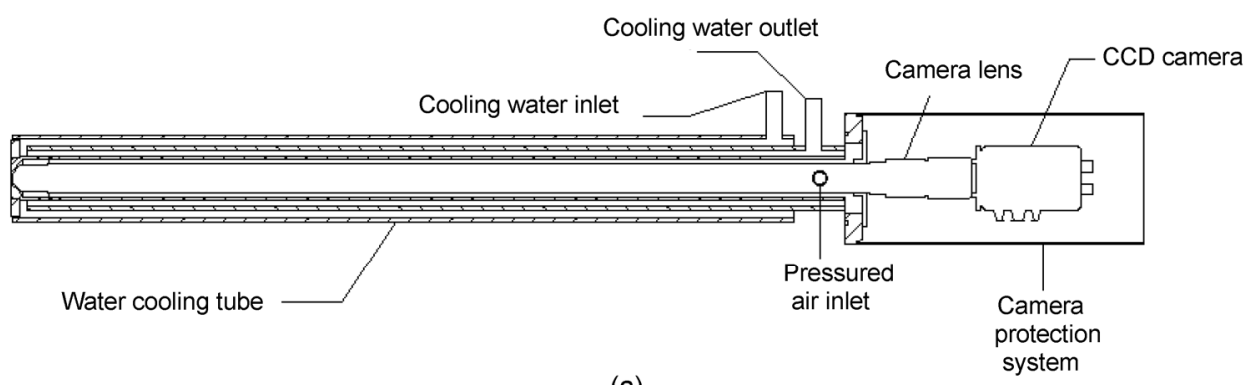

(a)

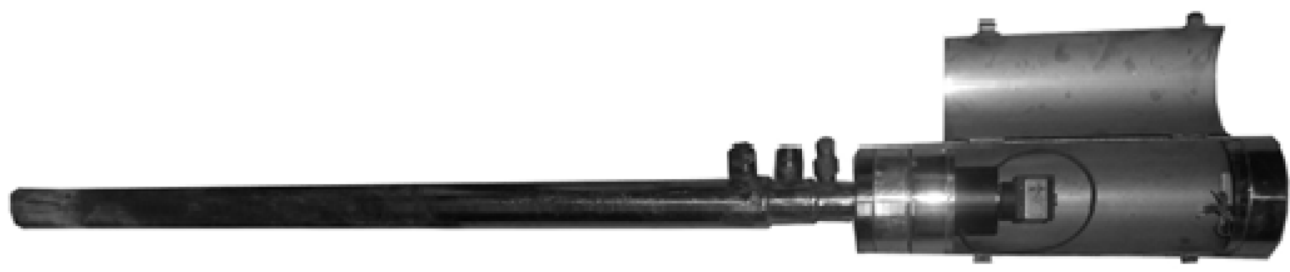

(b)

Fig. 4 CCD monitoring system (a) and CCD monitoring system detail (b) (Zhou et al., 2012)

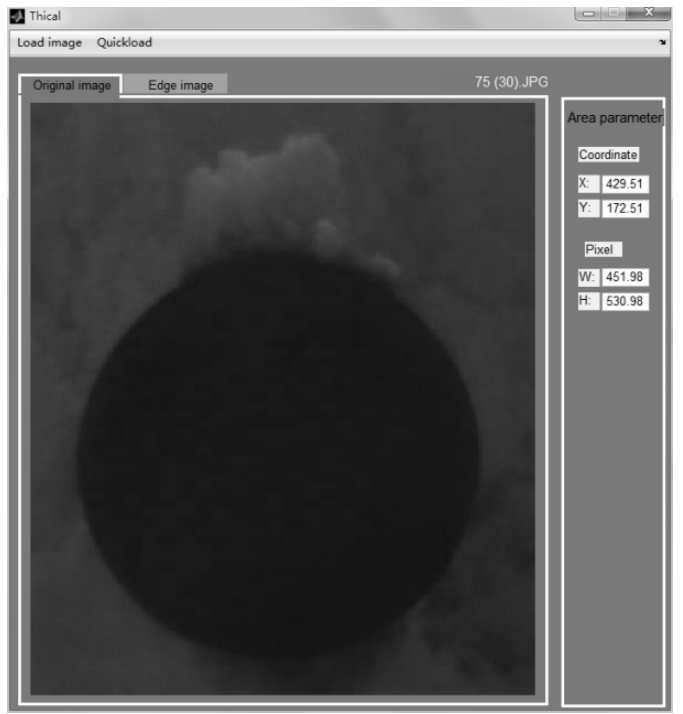

(a)

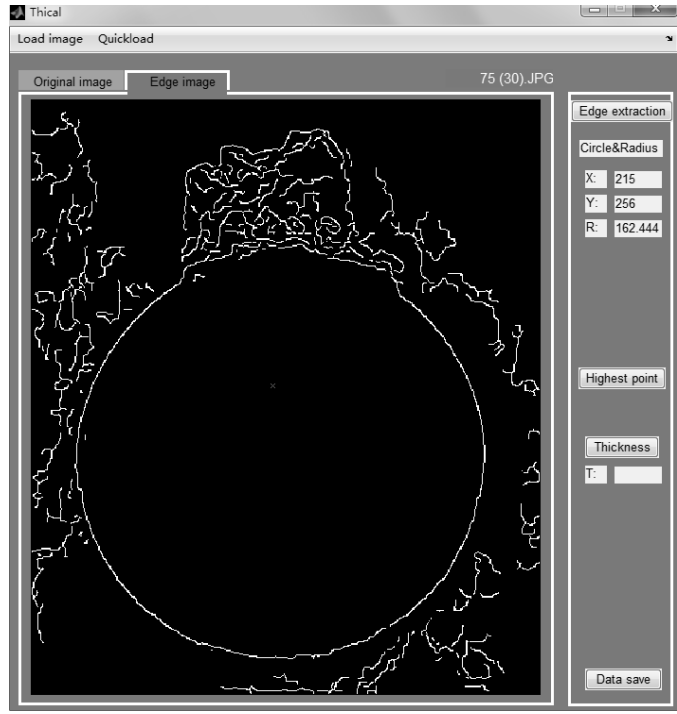

(b)

Fig. 5 Method of digital image processing: (a) original image; (b) edge image 
and (3) the slag layer (Rushdi et al., 2004). Previous studies obtained similar results for the deposits (Zhou et al., 2012). The color of the slag layer resulting from the three layers was generally darker than the initial layer. This is potentially due to different mineral content and the sintering degree of each layer.

\subsection{Growth of the deposits of different coals}

The thickness of the ash deposits was measured from the images to assess the ash deposit growth rate. In these experiments, the CCD camera took five pictures per second, which offered enough images to capture changes in the deposits, such as shedding.

Table 1 Analysis results for two tested coals

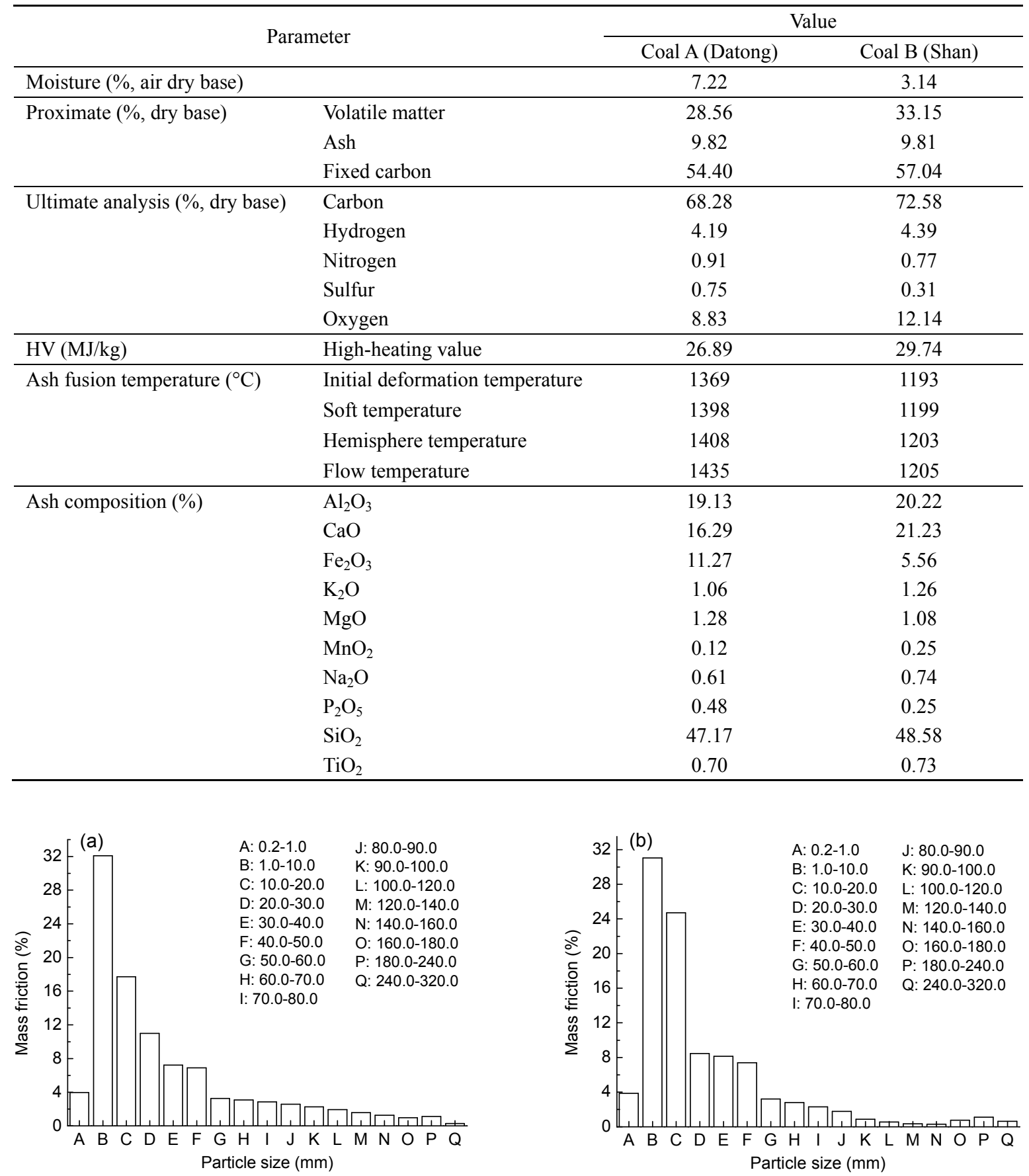

Fig. 6 Size distribution of two coals: (a) coal A; (b) coal B 


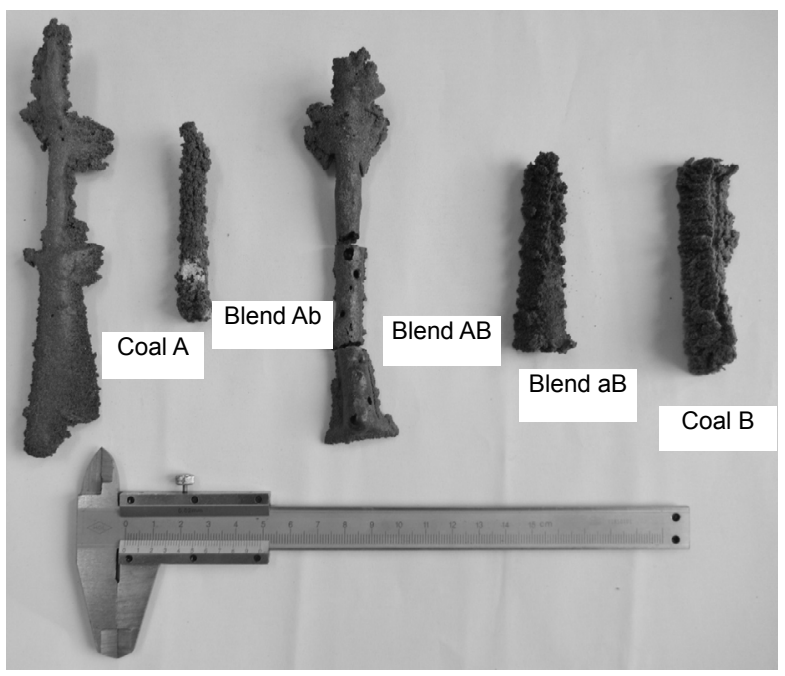

Fig. 7 Top view of five ash deposits from different coals and blends

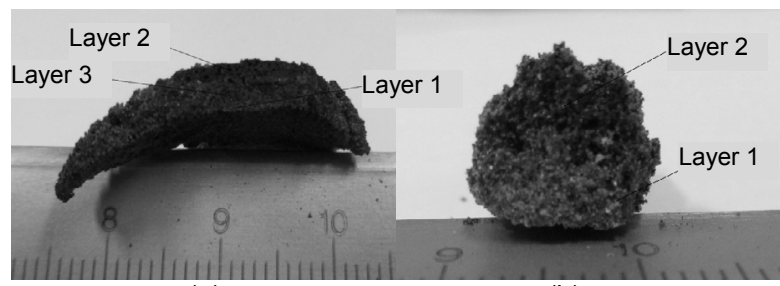

(a)

(b)

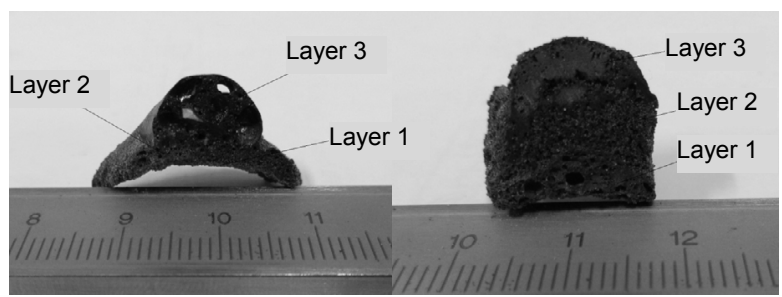

(c)

(d)

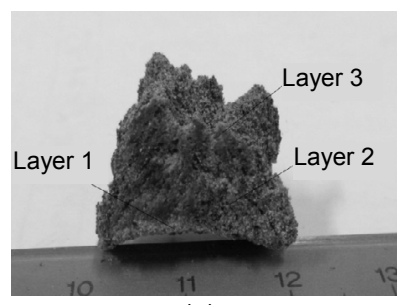

(e)

Fig. 8 Cross-sections of deposits collected from different coals and blends
(a) Coal A; (b) Blend $\mathrm{Ab}$; (c) Blend $\mathrm{AB}$; (d) Blend aB;
(e) Coal B

Consequently, an image was captured every $5 \mathrm{~min}$ from the monitoring video and analyzed to obtain the thickness of the slag.
The heat flux profile of each operating condition is illustrated in Fig. 9. The growth of the deposit with time and the heat flux through the probe versus thickness are shown in Fig. 10 and Fig. 11, respectively. The growth curves in Fig. 11 are composed of four sections with different rising rates. Based on this, the ash deposit process was separated into four stages: stage 1 ( stage $\left._{0-1}\right)$, stage $2\left(\right.$ stage $\left._{1-2}\right)$, stage $3\left(\right.$ stage $\left._{2-3}\right)$, and stage $4\left(\right.$ stage $\left._{3-4}\right)$. These stages were similar to the observations of the deposits, which, except for blend $\mathrm{Ab}$, had three layers. The deposits gradually reached a stable thickness, shown as zero slope lines in Fig. 10, and have been called the 'stable stage of slagging' (Kupka et al., 2008). In this stage, the thickness of the deposits changed slightly, which might have been caused by a force balance such as gravity, viscosity, and the surface force of the slag. For all five coals and blends, the time to reach stage 4 decreased from $200 \mathrm{~min}$ to $155 \mathrm{~min}$, with the increasing ratio of coal A. This might be because of the less slagging propensity of coal A. Meanwhile, the heat flux through the probe (Fig. 9) and the corresponding slag thickness (Fig. 11) fluctuated moderately in the final stage, which led to the aggregation of some data points in a circle. This might be the dynamic balance of the particle adhesion and the slag spread on the surface of the deposit in the stable stage. The board of deposits A and $\mathrm{AB}$ spread along the circle arc of the sampling part (Fig. 7).

The maximum heat flux came out at the initial time ranging from 290 to $320 \mathrm{~kW} / \mathrm{m}^{2}$, while the average heat flux in the stable stage decreased with the ratio of coal A. At the same time, the heat flux curves dropped sharply in stage 1 (Fig. 11). This suggested that the thermal conductivity near the probe was relatively low. This may result from the physical structure of the initial layer which is made up of fine particles adhering to the matrix with no obvious agglomeration.

\subsection{Microstructure of the ash deposits}

Figs. 12-16 (p.211) illustrate SEM pictures of the microstructure of each layer for the five deposits. These figures illustrate that the sintering degree increased from layer 1 to layer 3, which may have resulted from the different locations of each layer. As shown in Figs. 12a, 13a, 14a, 15a, and 16a, the initial layer was primarily composed of tiny round particles 


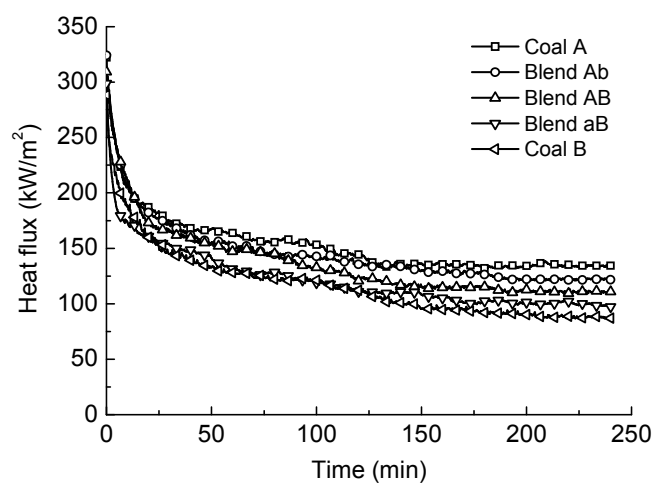

Fig. 9 Change of the thermal flux through the probes with time
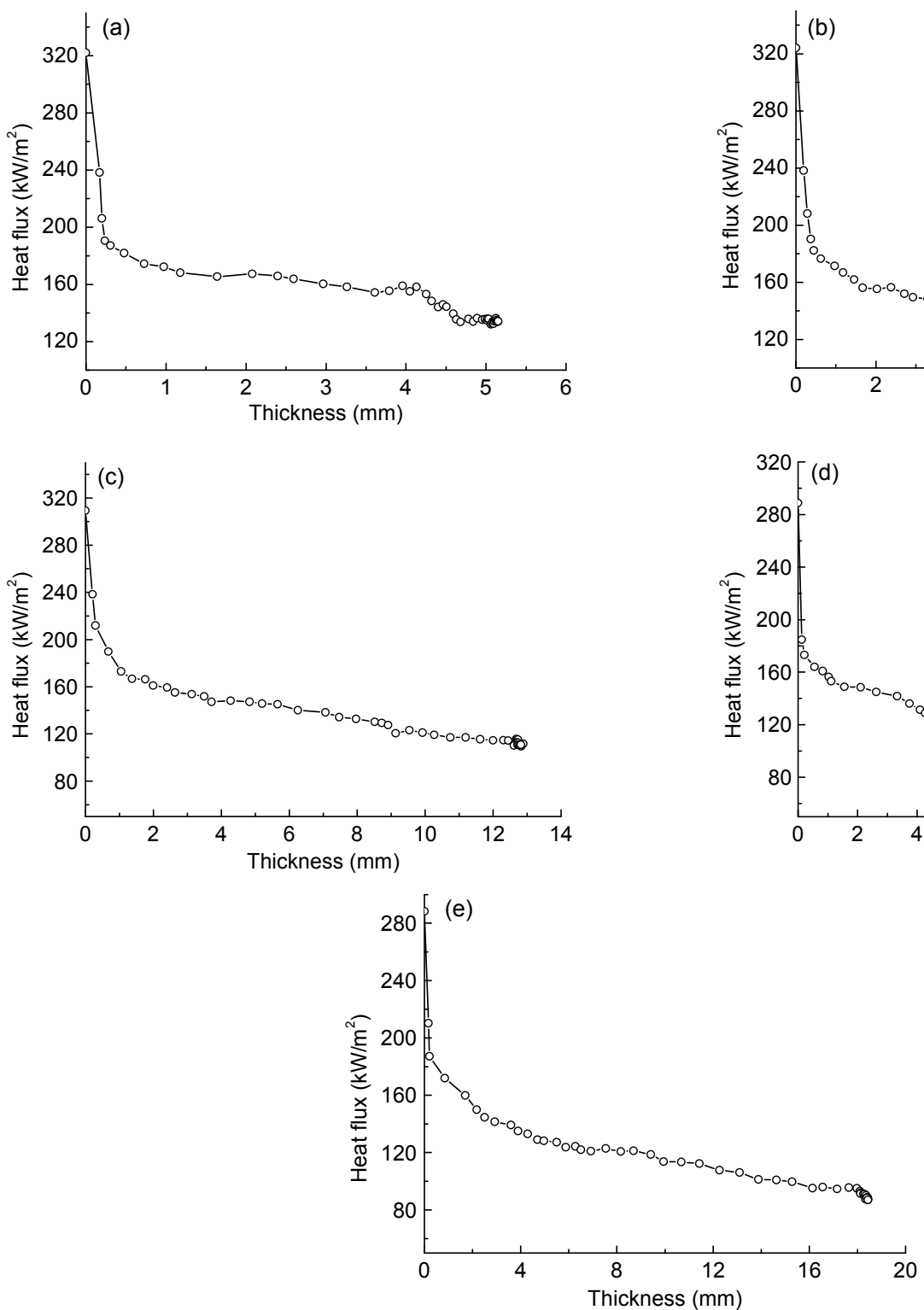

Fig. 11 Thermal flux across the ash deposition probe versus the deposit thickness

(a) Coal A; (b) Blend Ab; (c) Blend AB; (d) Blend aB; (e) Coal B
Fig. 10 Temperature of the third stage during the experiments
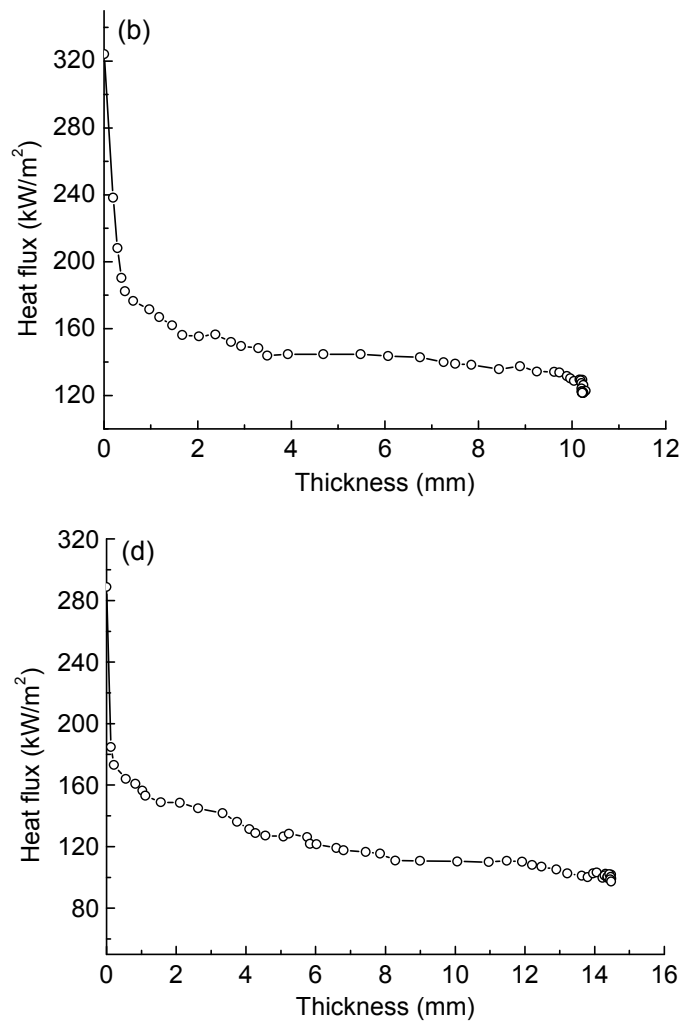


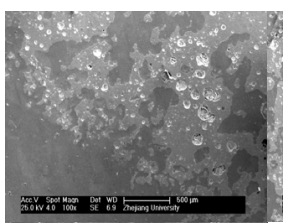

(a)

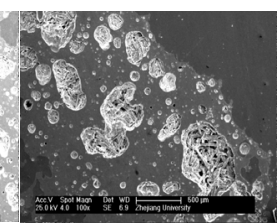

(c)

Fig. 12 SEM pictures of the microstructure for three layers of the deposit of coal A: (a) Layer 1; (b) Layer 2; (c) Layer 3

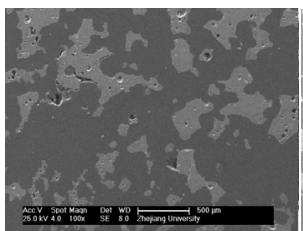

(a)

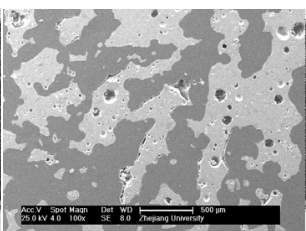

(b)

Fig. 13 SEM pictures of the microstructures for two layers of the deposit of blend Ab: (a) Layer 1; (b) Layer 2

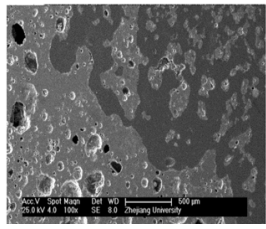

(a)

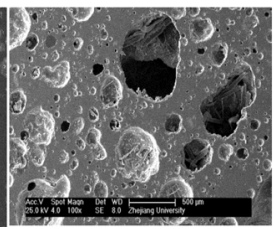

(b)

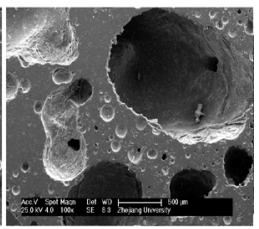

(c)

Fig. 14 SEM pictures of the microstructure for three layers of the deposit of blend AB: (a) Layer 1; (b) Layer 2; (c) Layer 3

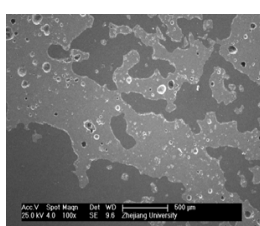

(a)

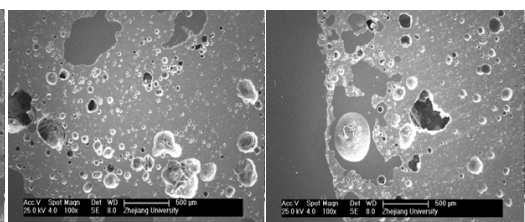

(b) (c)

Fig. 15 SEM picturess of the microstructure for three layers of the deposit of blend aB: (a) Layer 1; (b) Layer 2; (c) Layer 3

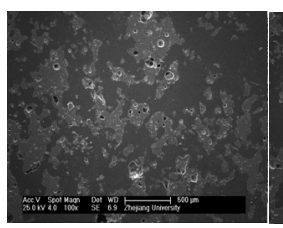

(a)

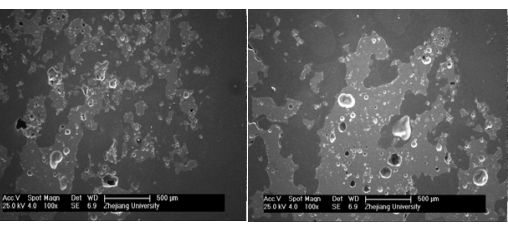

(b)

(c)

Fig. 16 SEM pictures of the microstructure for three layers of the deposit of coal B: (a) Layer 1; (b) Layer 2; (c) Layer 3 without significant agglomeration. The relatively loose structure concluded the low thermal conductivity of the initial layer, which was in accordance with the results mentioned in Section 3.2. As illustrated in Figs. $12 b, 13 b, 14 b, 15 b$, and $16 b$, there were some small irregular pores having different diameters in the sintered layer. This may have resulted from the shrinkage of the particles that occurred at a higher temperature, while the spherical particles were partially melted and dissolved in the deposits. The slag layer was full of large pores that bonded together (Figs. 12c, 14c, 15c, and 16c). This layer was highly sintered and led to a relatively high molten fraction in the slag. Therefore, based on the XRD results, a higher amount of amorphous material comprised the slag layer than that which was comprised in the initial layer.

\subsection{Elementary composition of ash deposit}

The elementary compositions of the five deposits were detected using SEM-EDX. Analytical results were normalized to $100 \%$ and presented in Table 2 with the oxides $\mathrm{SiO}_{2}, \mathrm{Al}_{2} \mathrm{O}_{3}, \mathrm{CaO}$, and $\mathrm{Fe}_{2} \mathrm{O}_{3}$ comprising more than $96 \%$ (by weight) of the deposits. The abundance of calcium and aluminum oxides indicates that the slag was potentially abundant in the calcium aluminosilicate. The XRD test presented in the following section validated that the slags contained great amounts of anorthite and other calcium aluminosilicates. Comparison of bulk composition between ash and different layers (Fig. 17) shows the abundance of the various mineral species in the deposits. In general, the deposits contained more $\mathrm{SiO}_{2}$ and $\mathrm{Fe}_{2} \mathrm{O}_{3}$, less $\mathrm{CaO}$ and $\mathrm{Al}_{2} \mathrm{O}_{3}$ than ash, indicating the selective deposition of these elements in the formation of the ash deposit.

\subsection{Mineralogy of the ash deposition by XRD detection}

The initial layer was comprised of various minerals (XRD results shown in Figs. 18-22) (p.213-215), being primarily quartz, albite, or anorthite. Mullite, ilvaite, diopside, and $\left(\mathrm{Ca}_{0.68} \mathrm{Na}_{0.32}\right)\left(\mathrm{Al}_{1.68} \mathrm{Si}_{0.32}\right) \mathrm{Si}_{2} \mathrm{O}_{8}$ were also present in lesser percentage compositions. However, the sintered and slag layers of coal $\mathrm{B}$ were primarily composed of $\left(\mathrm{Ca}_{0.68} \mathrm{Na}_{0.32}\right)\left(\mathrm{Al}_{1.68} \mathrm{Si}_{0.32}\right) \mathrm{Si}_{2} \mathrm{O}_{8}$ and quartz. This may have resulted from the lowpoint eutectic of the amorphous phase, which was the reaction product of iron oxide and aluminum silicates. 
Table 2 Elementary composition of each slag in different layers (\%)

\begin{tabular}{cccccccccr}
\hline Sample & Layer & $\mathrm{Na}_{2} \mathrm{O}$ & $\mathrm{MgO}$ & $\mathrm{Al}_{2} \mathrm{O}_{3}$ & $\mathrm{SiO}_{2}$ & $\mathrm{~K}_{2} \mathrm{O}$ & $\mathrm{CaO}$ & $\mathrm{TiO}_{2}$ & $\mathrm{Fe}_{2} \mathrm{O}_{3}$ \\
\hline \multirow{3}{*}{ Coal A } & 1 & 1.26 & 0.53 & 15.33 & 54.36 & 1.16 & 12.07 & 1.74 & 13.54 \\
& 2 & 0.70 & 0.92 & 17.36 & 53.70 & 1.50 & 10.42 & 1.56 & 13.84 \\
& 3 & 1.24 & 1.02 & 16.13 & 53.96 & 1.52 & 11.25 & 0.84 & 14.05 \\
\hline \multirow{2}{*}{ Blend $\mathrm{Ab}$} & 1 & 0.35 & 1.10 & 19.93 & 51.81 & 0.91 & 15.60 & 1.04 & 9.25 \\
& 2 & 0.59 & 1.09 & 17.84 & 53.01 & 1.22 & 14.82 & 1.22 & 10.17 \\
\hline \multirow{2}{*}{ Blend $\mathrm{AB}$} & 1 & 1.09 & 1.47 & 14.14 & 52.79 & 1.46 & 12.60 & 1.10 & 15.34 \\
& 2 & 0.97 & 1.10 & 12.74 & 53.58 & 1.70 & 11.32 & 1.69 & 16.88 \\
& 3 & 1.12 & 0.93 & 13.56 & 54.32 & 1.37 & 15.43 & 1.24 & 14.50 \\
\hline \multirow{3}{*}{ Blend aB } & 1 & 0.42 & 1.09 & 19.29 & 51.52 & 1.17 & 10.21 & 1.42 & 14.87 \\
& 2 & 0.50 & 0.86 & 18.50 & 52.98 & 1.33 & 11.00 & 1.47 & 13.36 \\
& 3 & 0.83 & 0.81 & 19.69 & 52.19 & 1.28 & 12.72 & 1.76 & 10.72 \\
\hline \multirow{2}{*}{ Coal B } & 1 & 0.47 & 1.54 & 12.30 & 56.91 & 1.66 & 14.64 & 1.89 & 10.58 \\
& 2 & 0.47 & 0.90 & 16.37 & 59.12 & 1.25 & 12.04 & 1.59 & 8.25 \\
& 3 & 0.69 & 0.53 & 17.42 & 54.44 & 1.33 & 16.85 & 1.48 & 7.26 \\
\hline
\end{tabular}
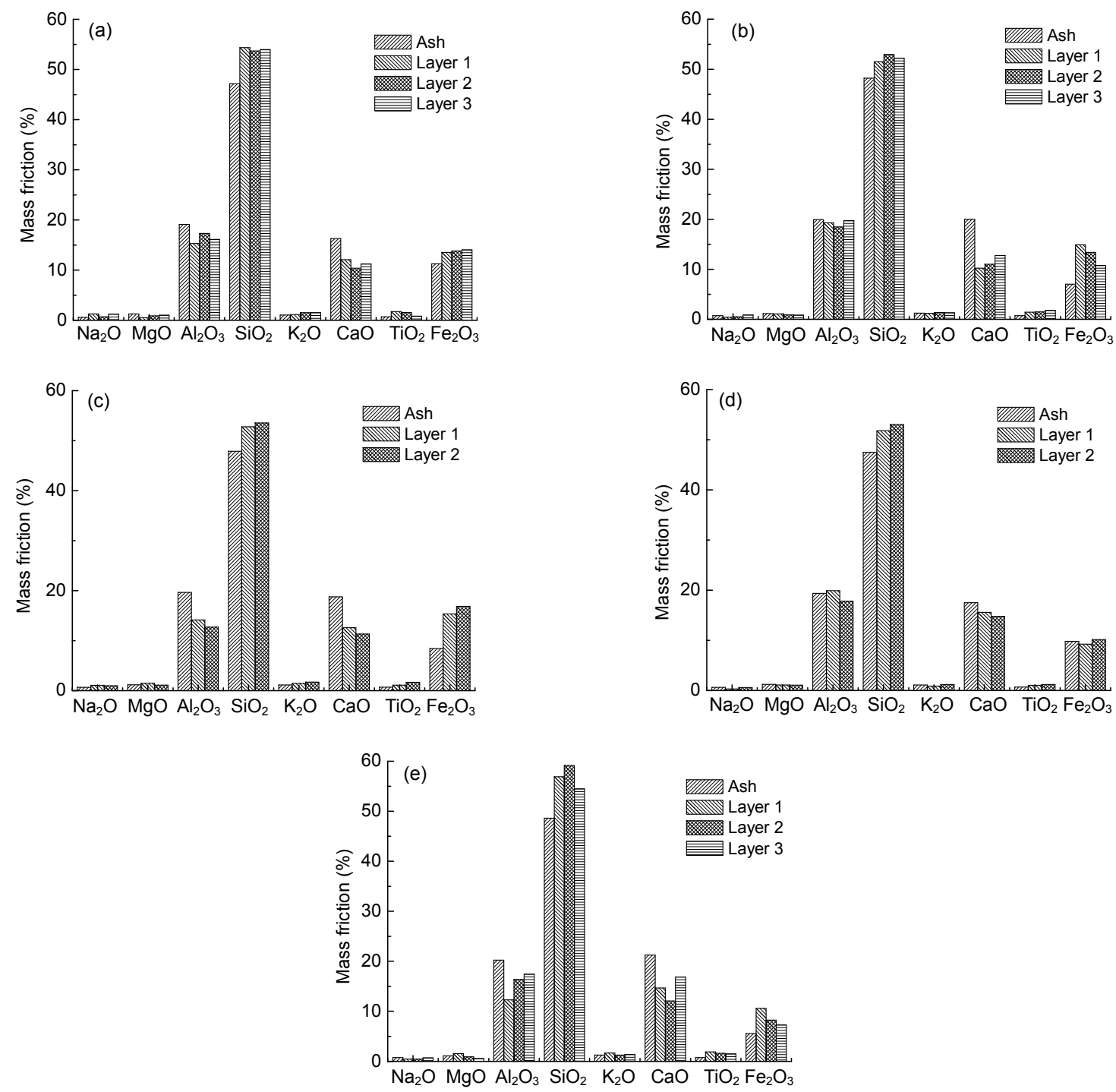

Fig. 17 Comparison of major oxides between coal ash and different layers

(a) Coal A; (b) Blend Ab; (c) Blend AB; (d) Blend aB; (e) Coal B 
a: Quartz-SiO

b: Anorthite- $-\mathrm{CaAl}_{2} \mathrm{Si}_{2} \mathrm{O}_{8}$

c: Diopside- $\mathrm{CaMgSi}_{2} \mathrm{O}_{6}$

d: Ilvaite-CaFe ${ }_{2} \mathrm{FeO}_{2}\left(\mathrm{Si}_{2} \mathrm{O}_{7}\right)$

e: $\left(\mathrm{Ca}_{0.68} \mathrm{Na}_{0.32}\right)\left(\mathrm{Al}_{1.68} \mathrm{Si}_{0.32}\right) \mathrm{Si}_{2} \mathrm{O}_{8}$

f: Halloysite- $\mathrm{Al}_{2} \mathrm{Si}_{2} \mathrm{O}_{5}(\mathrm{OH})_{4}$
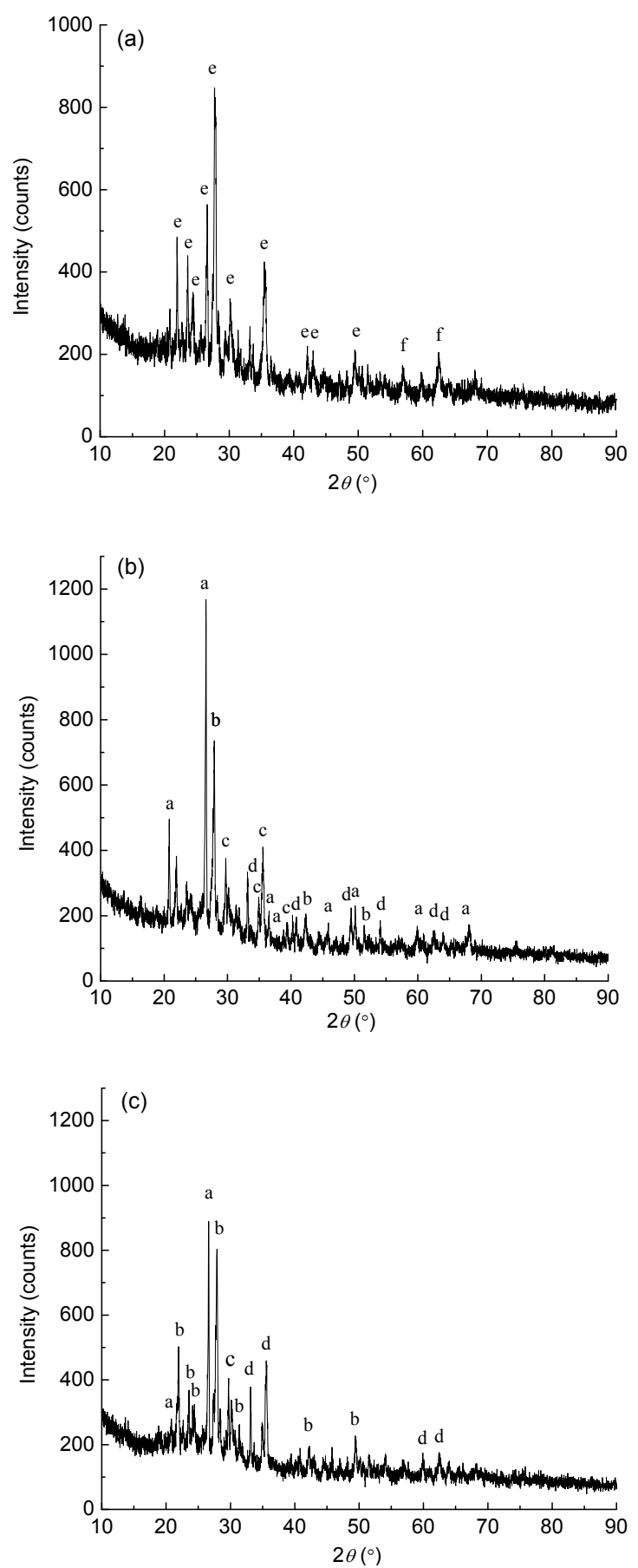

Fig. 18 XRD analysis of the deposit of coal $A$ (a) Layer 1; (b) Layer 2; (c) Layer 3
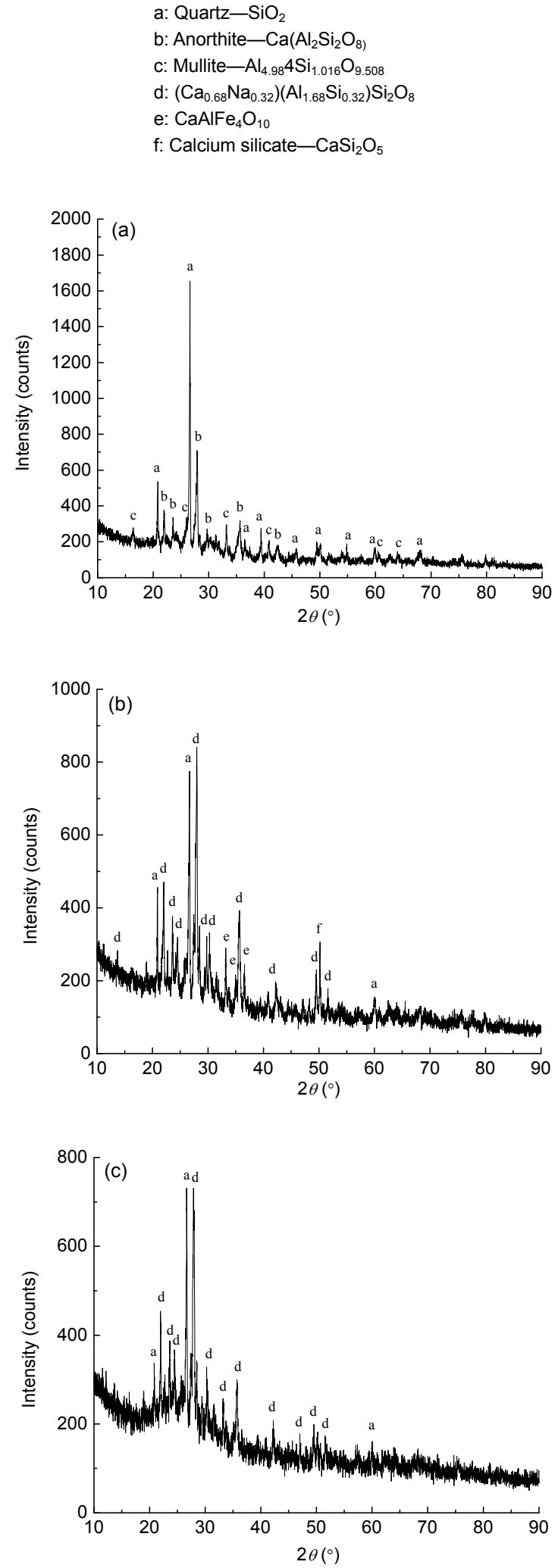

Fig. 19 XRD analysis of the deposit of blend Ab (a) Layer 1; (b) Layer 2; (c) Layer 3 


$$
\begin{aligned}
& \text { a: Quartz- } \mathrm{SiO}_{2} \\
& \text { b: Albite low-Na( } \left.\mathrm{AlSi}_{3} \mathrm{O}_{8}\right) \\
& \text { c: Diopside-CaMgSi } \mathrm{O}_{6} \\
& \text { d: }\left(\mathrm{Ca}_{0.68} \mathrm{Na}_{0.32}\right)\left(\mathrm{Al}_{1.68} \mathrm{Si}_{0.32}\right) \mathrm{Si}_{2} \mathrm{O}_{8} \\
& \text { e: Rankinite- } \mathrm{Ca}_{3} \mathrm{Si}_{2} \mathrm{O}_{7}
\end{aligned}
$$
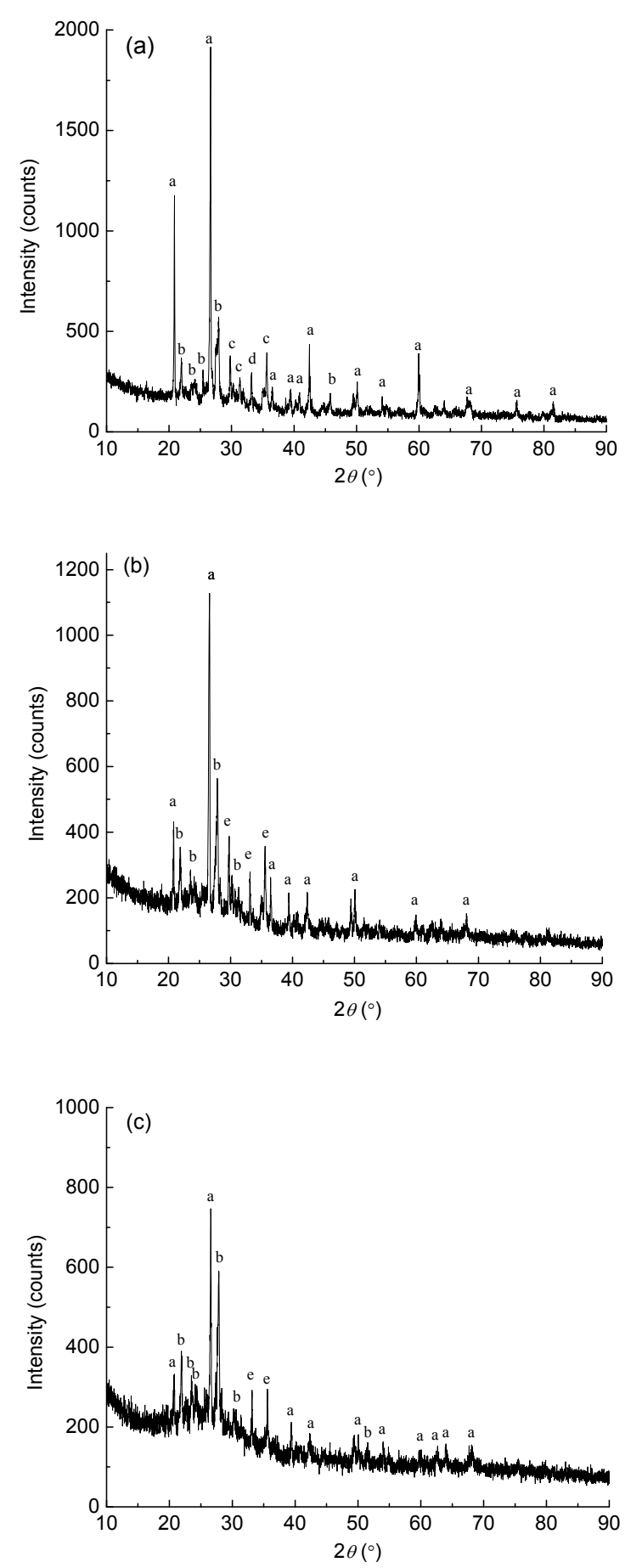

Fig. 20 XRD analysis of the deposit of blend AB (a) Layer 1; (b) Layer 2; (c) Layer 3
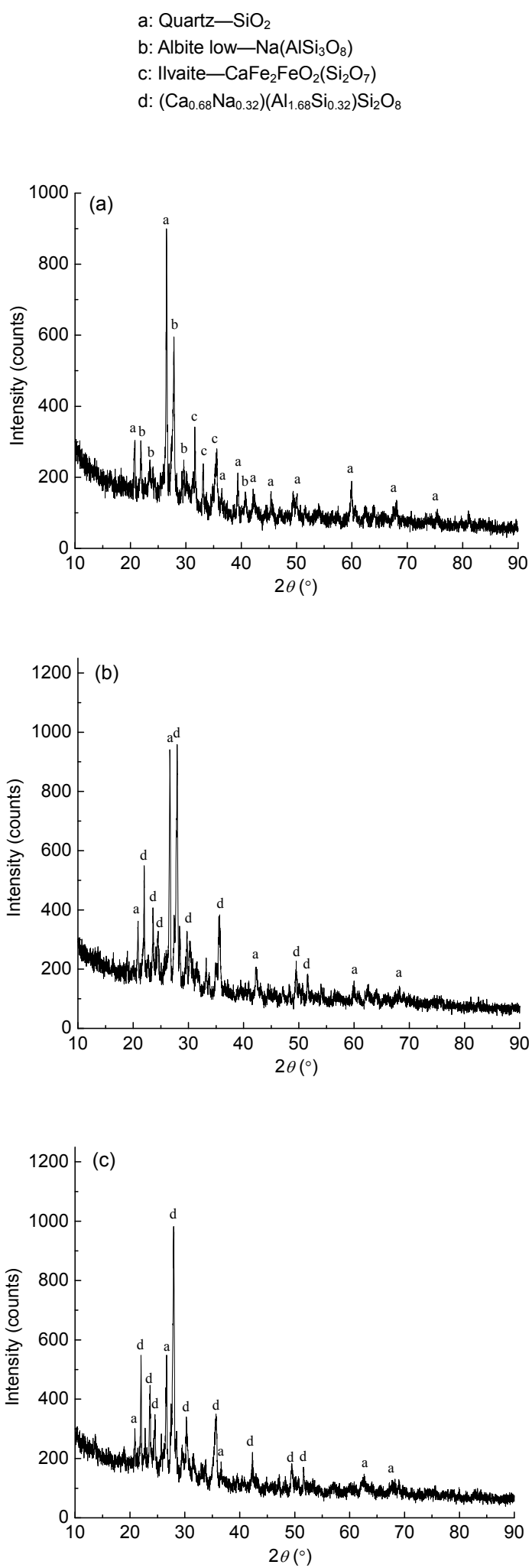

Fig. 21 XRD analysis of the deposit of blend aB (a) Layer 1; (b) Layer 2; (c) Layer 3 
a: Quartz- $\mathrm{SiO}_{2}$

b: $\left(\mathrm{Ca}_{0.68} \mathrm{Na}_{0.32}\right)\left(\mathrm{Al}_{1.68} \mathrm{Si}_{0.32}\right) \mathrm{Si}_{2} \mathrm{O}_{8}$

c: Ilvaite- $-\mathrm{CaFe}_{2} \mathrm{FeO}_{2}\left(\mathrm{Si}_{2} \mathrm{O}_{7}\right)$

d: Sodium aluminum silicate- $-\mathrm{NaAISiO}_{4}$
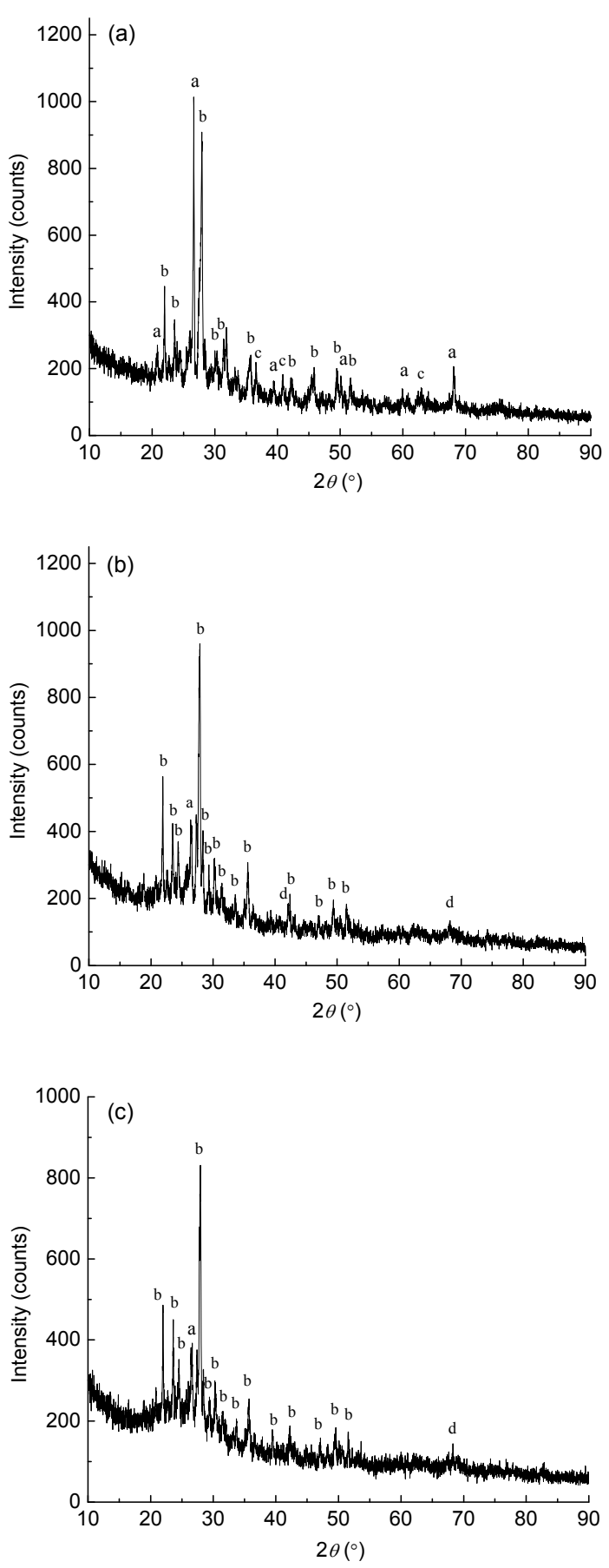

Fig. 22 XRD analysis of the deposit of coal $B$ (a) Layer 1; (b) Layer 2; (c) Layer 3
Quartz content decreased along the deposit growth orientation, which could have been due to the melting of quartz and solidification into an amorphous phase near the flame zone.

\section{Conclusions}

This study investigated the slagging characteristics of blended coals in a pilot-scale bench experiment applying digital imaging techniques. The thickness of the five deposits were $5.1,10.2,12.8,14.5$, and $18.4 \mathrm{~mm}$, increasing with the ratio of coal $\mathrm{B}$. The slagging severity of the three blends were different between that of the component coals which suggested no great nonlinear interaction happened on the sampling probe. The time to reach the stable stage increased with the ratio of coal B.

The elementary composition of the five deposits showed that silicon, aluminum, and calcium occupied a large proportion in the deposits, which affected ash deposition. According to the result of XRD analysis, quartz, albite, anorthite, and $\left(\mathrm{Ca}_{0.68} \mathrm{Na}_{0.32}\right)\left(\mathrm{Al}_{1.68} \mathrm{Si}_{0.32}\right) \mathrm{Si}_{2} \mathrm{O}_{8}$, decreased along the direction of the deposit growth.

\section{References}

Arvelakis, S., Folkedahl, B., Johansen, K.D., et al., 2006. Studying the melting behavior of coal, biomass, and coal/biomass ash using viscosity and heated stage XRD data. Energy \& Fuels, 20(3):1329-1340. [doi:10.1021/ ef050168b]

Degereji, M.U., Ingham, D.B., Ma, L., 2012. Numerical assessment of coals/blends slagging potential in pulverized coal boilers. Fuel, 102:345-353. [doi:10.1016/j.fuel.2012. 07.028]

Gupta, R.P., Rushdi, A., Browning, G., et al., 2001. A mechanistic approach for assessing thermal performance of coal blends. Proceedings of the Engineering Foundation Conference on Impact of Fuel Quality on Power Generation, Utah, USA.

Kostakis, G., 2011. Mineralogical composition of boiler fouling and slagging deposits and their relation to fly ashes: the case of Kardia power plant. Journal of Hazardous Materials, 185(2-3):1012-1018. [doi:10.1016/j.jhazmat.2010. 10.006]

Kupka, T., Mancini, M., Irmer, M., et al., 2008. Investigation of ash deposit formation during co-firing of coal with sewage sludge, saw-dust and refuse derived fuel. Fuel, 87(12): 2824-2837. [doi:10.1016/j.fuel.2008.01.024] 
Ma, Z., Iman, F., Lu, P., et al., 2007. A comprehensive slagging and fouling prediction tool for coal-fired boilers and its validation/application. Fuel Processing Technology, 88(11-12):1035-1043. [doi:10.1016/j.fuproc.2007.06.025]

Richards, G.H., Slater, P.N., Harb, J.N., 1993. Simulation of ash deposit growth in pulverized coal-fired pilot scale reactor. Energy \& Fuels, 7(6):774-781. [doi:10.1021/ ef00042a012]

Rushdi, A., Gupta, R., 2005. Investigation of coals and blends deposit structure: measuring the deposit bulk porosity using thermomechanical analysis technique. Fuel, 84(5): 595-610. [doi:10.1016/j.fuel.2004.09.021]

Rushdi, A., Sharma, A., Gupta, R., 2004. An experimental study of the effect of coal blending on ash deposition. Fuel, 83(4-5):495-506. [doi:10.1016/j.fuel.2003.08.013]

$\mathrm{Su}$, S., 1999. Combustion behavior and ash deposition of blended coals. Proceedings of the Chemical engineering, Brisbane, Australia.

$\mathrm{Su}$, S., Pohl, J.H., Holcombe, D., et al., 2001. Slagging propensities of blended coals. Fuel, 80(9):1351-1360. [doi:10.1016/S0016-2361(00)00214-3]

Su, S., Pohl, J.H., Holcombe, D., 2003. Fouling propensities of blended coals in pulverized coal-fired power station boilers. Fuel, 82(13):1653-1667. [doi:10.1016/S0016-2361 (03)00071-1]

Wang, H., Harb, J.N., 1997. Modeling of ash deposition in large-scale combustion facilities burning pulverized coal. Progress in Energy and Combustion Science, 23(3): 267-282. [doi:10.1016/S0360-1285(97)00010-5]

Zhou, H., Zhou, B., Qu, H., et al., 2012. Experimental investigation of the growth of ash deposits with and without ad- ditives through a digital image technique. Energy \& Fuels, 26(11):6824-6833. [doi:10.1021/ef301093j]

\section{中文概要}

题 目: 中试台架上混煤结渣特性实验研究

目 的：混煤掺烧方式广泛应用于电站的实际生产中, 但 实际生产中出现了比源煤更为严重的结渣情况。 为了研究混煤结渣特性, 本文在中试台架上进行 混煤结渣实验。

创新点: 在实验过程中采用 $\mathrm{CCD}$ 相机全程监控灰渣生长 情况, 通过对图片进行图像处理, 可以获取灰渣 的动态生长情况, 更为详细地了解结渣特性。

方 法: 1. 在中试台架上燃烧不同比例配制的大同煤和陕 煤的混煤, 插入结渣探针和 $\mathrm{CCD}$ 探针进行结渣 实验; 2 . 对煤灰进行 $X$ 射线荧光 $(X R F)$ 分析获 取氧化物含量; 3 . 对灰渣横截面进行扫描电子显 微术-能量色散 X 射线分析 (SEM-EDX)，取不同 层的粉末进行 X 射线衍射 (XRD) 分析。

结 论: 1. 混煤结渣厚度随着陕煤比例的增加而增加; 2 . 各 工况下结渣达到稳态所需时间随着陕煤比例增 加而增加; 3. 灰渣截面都出现了明显的分层情 况, 主要元素在飞灰和灰渣之间有明显的选择性 沉积。

关键词: 混煤; 灰沉积; 结渣; $\mathrm{CCD}$ 相机; 矿物学 